\title{
Cetylpyridinium Chloride as a Tool Against COVID-19
}

\author{
Cloruro de Cetilpiridinio como Herramienta para Combatir el COVID-19
}

\author{
Sebastián Pérez-Errázuriz'; Eugenio Velasco-Ortega'; Álvaro Jiménez-Guerra' \& Eduardo Aguilera-Navarro²
}

PÉREZ-ERRÁZURIZ, S.; VELASCO-ORTEGA, E.; JIMÉNEZ-GUERRA, A. \& AGUILERA-NAVARRO, E. Cetylpyridinium chloride as a tool against COVID-19. Int. J. Odontostomat., 15(1):27-30, 2021.

ABSTRACT: As a part of bringing knowledge to healthcare professional, our team searched in the literature the effectiveness of Cetylpyridinium Chloride over SARS-CoV-2. Objectives: Explore the efficacy of Cetylpyridinium Chloride as a mouthwash in the dental attention. Methods: A literature search was realized in PubMed (MEDLINE), with the focusing on the following words: "Cetylpyridinium Chloride", "COVID-19", "Mouthwash", up to June 30, 2020. Results: There is a few information of this biocide over lower and upper airway affection, and other microorganisms. The effect of Cetylpyridinium Chloride over SARS-CoV-2 has not been proved. Although different guidelines recommend oxidative agents as a mouthwash before dental attention. Conclusion: Cetylpyridinium chloride is a cationic biocide widely used as a disinfectant in dentistry and as a mouthwash. Nevertheless, more research is needed, to know the effectiveness of CPC over SARS-CoV-2.

KEYWORDS: Cetylpyridinium Chloride, COVID-19, mouthwash.

\section{INTRODUCTION}

Inhalation of infected aerosols is the main form of transmission. The mouth is considered an open gate to infectious agents, and it is directly related with SARS-CoV-2 virus. The main components of some mouthwashes could help to reduce the virobiota, and may also be a helpful way to control de dissemination of the microorganisms. Cetylpyridinium Chloride is a broad-spectrum biocide used in dentistry; it's main function is to disrupt the lipid layer of the virus membrane. This mentioned effect referred to the alteration of the lower and upper airways has been studied previously with other viruses, but not with the SARS-CoV-2 specifically.

\section{METHOD}

The search was performed in PubMed (MEDLINE), focusing on "Cetylpyridinium Chloride", "COVID-19" and "Mouthwash", up to June 30, 2020.

\section{RESULTS}

SARS CoV-2. Experts of the International Committee on Taxonomy of Viruses are calling: SARS-CoV-2, because it has the exact same entry receptor as SARS-CoV (Kannan et al., 2020). SARSCoV-2 could be attached to the human angiotensinconverting enzyme 2 (ACE-2), the same receptor that is in the mouth mucosa and in the epithelial cell of the tongue (Xu et al., 2020).

Affecting over 160 countries in the world, with a high rate of dead $8 \%$ (Amariles et al., 2020), is the main public threat these days, due to the lack of an effective vaccine.

SARS-CoV-2 has a spherical shape and its size is between 120 to $160 \mathrm{nn}$. It has a singlestranded large RNA, with four structural proteins: the spike $(S)$ protein, the nucleocapsid $(N)$ protein, the membrane $(\mathrm{M})$ protein, and the envelope $(\mathrm{E})$ protein (Schoeman \& Fielding, 2019; Odeh et al., 2020).

\footnotetext{
1 Universidad de Sevilla, Seville, Spain Faculty of Dentistry, Department of Stomatology, Spain.

${ }^{2}$ Universidad del Desarrollo, Santiago, Chile. Faculty of Dentistry, Department of Periodotology, Chile.
} 
The virus's amino acid sequence varies from others Coronavirus in the labs polyprotein and in the S-protein (Kannan et al.). The real-time RT-PCR technique and the genomic sequencing techniques are the two tests used to confirm the diagnosis of COVID19-19 (Kannan et al.).

The main way of transmission has been described by Flügge droplets (remain on surface or floor, but not the air) and Wells droplets nuclei, (remain in the air for hours) both are expelled from the oral cavity when talking or coughing (Herrera et al., 2020).

\section{Infective Control in the Dental Care}

Dental field is placed in the highest-risk categories on spread of the virus (Odeh et al.). Dental procedures are a potential source of cross contamination, including the oral microbiota, also contains pathogenic bacteria and viruses (HIV, hepatitis $B$ and $C$, herpes simplex, influenza and rhinovirus), all these which can remain suspended and stay active for long periods of time (Marui et al., 2019). In the oral cavity, SARS-CoV-2 can be present by the constant exchange of fluids and droplets from the lower and upper airways, in the release of crevicular blood serum and on infected salivary glands (Chessa et al., 2020).

Nowadays, the main objective of dentistry is to have an effective dental treatment following specifics protocols in order to maintain control of the virus for the healthcare of patients and doctors. This include personal protective equipment (PPE), with eye protection, N95 mask, face shield, gloves, rubber boots, head cover and gown (Ather et al., 2020).

Effects of Cetylpyridinium chloride on SARS-CoV2. Quaternary Ammonium (QA) are cationic biocides, with the potential to interfere in the bacteria's membrane functions, bacterial adhesion and glucose uptake (Dimkov et al., 2006). QA has the ability to be sporostatic (inhibit the outgrowth of spores), and also has the possibility to induce disintegration on lipid envelope's virus (including human immunodeficiency and Hepatitis B) (McDonnell \& Russell, 1999). Due to this action, it suggested that this QA act against coronavirus (Herrera et al.). Its interaction with microorganisms starts with the adsorption and the entrance into the cell, followed by the disorganization of the lipid membrane and an infiltration in the intracellular material, which produces a degradation of proteins and nucleic acids, ending with the lysis of the wall, caused by autolytic enzymes (Gerba, 2015).
Cetylpyridinium Chloride (CPC) is a well know QA, that has been used for decades for many pathogens, including bacterial and fungal infections (Popkin et al., 2017). The inhalation of CPC in concentration of $0,05 \%$ (medical application) in aerosols, could cause pulmonary inflammation in mice, and a toxic reaction in the respiratory system in humans, although further research is needed (Kanno et al., 2020). Nevertheless, the FDA banned some of the products that contained $\mathrm{QA}$, and controlled its concentration level in others for safety issues.

The knowledge of the interaction of CPC in viruses is limited. An in vitro study demonstrated the damaging effect of CPC in the maturation and the replication of Hepatitis $B$ virus (HBV), with an insignificant consequence on the viability of the cell (Seo et al., 2019). The effectiveness against respiratory viruses is still unclear, and there is very little evidence around it (Popkin et al.). Although a recent systematic review, concluded that, there is a moderate evidence on its ability to reduce the number of viable bacteria in the oral cavity $(64,8 \%)$ (Marui et al.).

So far, there is no research that proves the effectiveness of any mouthwash over the SARS-CoV2 (Sigua-Rodríguez et al.), although the in vivo and in vitro studies executed by the University Hospitals Cleveland Medical Center \& University of Chicago demonstrated that CPC could reduce the influenza virus infectivity by $50 \%$, following 5 minutes of exposure, and $90 \%$ at 90 minutes (Popkin et al.). This is consistent with what is indicated in another doubled-blind placebocontrolled clinical trial, which indicates that CPC provides a protection barrier on the alveolar mucosa, preventing viral contact and its invasion, thus being an effective treatment for decreasing influenza symptoms (Mukherjee et al., 2017).

At present, the Australian Dental Association, recommended the use of hydrogen peroxide $1 \%$, povidone iodine $0,2 \%$, chlorhexidine $0,2 \%$ as preprocedural mouth rinse, this is supported by the Colleagues of dentist of Spain, the British Endodontic Society, and Us. Department of Health and Human Service (President, 2020)(Kohn et al., 2004).

\section{DISCUSSION}

The virus can enter the cells, by the transmembrane protein angiotensin-converting 
enzyme (ACE2). There is evidence, that demonstrate the presence of this receptor, in the oral epithelial cells in oral $\operatorname{cavity}(\mathrm{Xu}$ et al.). There is a high presence of this virus, in the early stage of the infection of COVID19 in asymptomatic patients, and the oral cavity is suggested reservoir (Herrera et al.).

Rotatory instrument in dental attention generates aerosols and can result a high heavily loaded droplets with microorganisms, that can be in the air for hours, depending on particle size (Pitten \& Kramer, 2001). The high risk of contagious before the procedure, makes the need of a biocide that contribute in a reduction in the number of microorganism, reducing the risk of cross-contamination, helping to protect dentist and patients (Marui et al.).

Cetylpiridinium Chloride is an antimicrobial used as detergents and antiseptics, with a fast bactericidal effect in gram- positive and negative pathogens and fungicides, being able to reduce bacterial counts, of 2.0 to $2.5 \mathrm{log}$ steps (adequate to $>99 \%$ ) (Pitten \& Kramer, 2001). Actually, is a topic of research due to the lack of information about its effectiveness on SARS-CoV-2. The effectiveness and toxicity depend on the concentration, and time of exposure of this biocide. Antiseptic of this mouthwash before a dental procedure is recommended by authors, to decrease different microorganisms on contaminated aerosol. Although, dental professional must be aware, about the inhalation by patients to avoid alterations in cells lung (Kanno et al.).

The effectiveness against influenza virus, suggests that there could be a preventive action of the CPC against respiratory infections, but more studies are needed (Mukherjee et al.; Popkin et al.). Nowadays authors recommend using hydrogen peroxide $1 \%$ due to the virus is vulnerable to oxidation, or povidone iodine $1 \%$ (Chessa et al., 2020)(Peng et al., 2020).

This short research could be a starting point of future investigations. Moreover, our review is in accordance that CPC mouthwash in $0,05 \%$ is an effective way to reduce microorganism in the oral cavity and surfaces (Pitten \& Kramer; Marui et al.; SiguaRodríguez et al.).

CONCLUSION. Cetylpyridinium Chloride as a mouthwash may be able to reduce the viral load, produced during the dental attention. Although, there must be more pre-clinical and clinical studies about to support these possibilities.
PÉREZ-ERRÁZURIZ, S.; VELASCO-ORTEGA, E.; JIMÉNEZ-GUERRA, A. \& AGUILERA-NAVARRO, E. Cloruro de cetilpiridinio como herramienta para combatir el COVID-19. Int. J. Odontostomat., 15(1):27-30, 2021.

RESUMEN:Como parte de entregar el conocimiento al personal medico, nuestro equipo ha realizado una búsqueda sobre la eficacia del Cloruro Cetilpiridinio (CPC) sobre el virus SARS-CoV-2. Objetivos: Explorar la eficacia del CPC como uso de colutorio en la atención dental. Material y Metodos: Busqueda en la literatura mediante Pubmed (MEDLINE), con enfoque en las palabras Cloruro Cetilpiridinio,COVID-19, Colutorio, hasta Junio 30,2020. Resultados: Existe escasa información sobre este biocida y su efecto en las vias respiratorias altas y bajas, como frente a otros microrganismos. El efecto de CPC sobre SARS-CoV2 no se ha visto del todo comprobado. Sin embargo diferentes protocolos de actuación dental recomiendan el uso de agentes oxidantes como colutorio previo a la atención dental. Conclusión: CPC es un biocida cationico ampliamente utilizado como desinfectante en la odontología. Sin embargo se necesita mayor evidencia cientifica para demostrar la eficiencia del CPC por sobre SARS-CoV-2.

PALABRAS CLAVE: cloruro cetilpiridinio,COVID19, colutorio.

\section{REFERENCES}

Amariles, P.; Granados, J.; Ceballos, M. \& Montoya, C. J. COVID19 in Colombia endpoints. Are we different, like Europe? Res. Social Adm. Pharm., 2020. DOI: https://www.doi.org/10.1016/ j.sapharm.2020.03.013

Ather, A.; Patel, B.; Ruparel, N. B.; Diogenes, A. \& Hargreaves, K. M. Coronavirus Disease 19 (COVID-19): implications for clinical dental care. J. Endod., 46(5):584-95, 2020.

British Endodontic Society. Diagnosis and Management of Endodontic Emergencies, a British Endodontic Society Position Paper for Primary Dental Care and Other Healthcare Providers during the COVID-19 Pandemic. Saint Albans, British Endodontic Society, 2020. Available from: https://britishendodonticsociety. org.uk/wp-content/uploads/2020/03/BES-Emergency-ProtocolFINAL-DOCUMENT-29-MARCH-2020.pdf

Dimkov, A.; Panovski, N.; Stevanovic, M. \& Gjorgievska, E. Effects of cetylpyridinium chloride in overall and caryogenic salivary micro flora reduction. Balk. J. Stomatol., 10:1-10, 2006.

Gerba, C. P. Quaternary ammonium biocides: efficacy in application. Appl. Environ. Microbiol., 81(2):464-9, 2015.

Herrera, D.; Serrano, J.; Roldán, S. \& Sanz, M. Is the oral cavity relevant in SARS-CoV-2 pandemic? Clin. Oral Investig., 2020. DOI: https://www.doi.org/10.1007/s00784-020-03413-2

Kannan, S.; Ali, P. S. S.; Sheeza, A. \& Hemalatha, K. COVID-19 (Novel Coronavirus 2019) - recent trends. Eur. Rev. Med. Pharmacol. Sci., 24(4):2006-11, 2020.

Kanno, S.; Hirano, S.; Kato, H.; Fukuta, M.; Mukai, T. \& Aoki, Y. Benzalkonium chloride and cetylpyridinium chloride induce apoptosis in human lung epithelial cells and alter surface activity of pulmonary surfactant monolayers. Chem. Biol. Interact., 317:108962, 2020 
Kohn, W. G.; Collins, A. S.; Cleveland, J. L.; Harte, J. A.; Eklund, K. J.; Malvitz, D. M. \& Centers for Disease Control and Prevention (CDC). Guidelines for infection control in dental health-care settings--2003. MMWR Recomm. Rep., 52(RR-17):1-61, 2003.

Marui, V. C.; Souto, M. L. S.; Rovai, E. S.; Romito, G. A.; Chambrone, L. \& Pannuti, C. M. Efficacy of preprocedural mouthrinses in the reduction of microorganisms in aerosol: A systematic review. J. Am. Dent. Assoc., 150(12):1015-1026.e1, 2019.

McDonnell, G. \& Russell, A. D. Antiseptics and disinfectants: activity, action, and resistance. Clin. Microbiol. Rev., 12(1):147-79, 1999.

Mukherjee, P. K.; Esper, F.; Buchheit, K.; Arters, K.; Adkins, I.; Ghannoum, M. A. \& Salata, R. A. Randomized, double-blind, placebo-controlled clinical trial to assess the safety and effectiveness of a novel dual-action oral topical formulation against upper respiratory infections. BMC Infect. Dis., 17:74, 2017.

Odeh, N. D.; Babkair, H.; Abu-Hammad, S.; Borzangy, S.; AbuHammad, A. \& Abu-Hammad, O. COVID-19: present and future challenges for dental practice. Int. J. Environ. Res. Public Health, 17(9):3151, 2020.

Peng, X.; Xu, X.; Li, Y.; Cheng, L.; Zhou, X. \& Ren, B. Transmission routes of 2019-nCoV and controls in dental practice. Int. J. Oral Sci., 12(1):9, 2020.

Pitten, F. A. \& Kramer, A. Efficacy of cetylpyridinium chloride used as oropharyngeal antiseptic. Arzneimittelforschung, 51(7):58895, 2001.

Popkin, D. L.; Zilka, S.; Dimaano, M.; Fujioka, H.; Rackley, C.; Salata, R.; Griffith, A.; Mukherjee, P. K.; Ghannoum, M. A. \& Esper, F. Cetylpyridinium chloride (CPC) exhibits potent, rapid activity against influenza viruses in vitro and in vivo. Pathog. Immun., 2(2):252-69, 2017.

Schoeman, D. \& Fielding, B. C. Coronavirus envelope protein: current knowledge. Virol. J., 16(1):69, 2019.

Seo, H. W.; Seo, J. P.; Cho, Y.; Ko, E.; Kim, Y. J. \& Jung, G. Cetylpyridinium chloride interaction with the hepatitis $\mathrm{B}$ virus core protein inhibits capsid assembly. Virus Res., 263:102-11, 2019.

Sigua-Rodríguez, E. A.; Bernal-Pérez, J. L.; Lanata-Flores, A. G.; Sánchez-Romero, C.; Rodríguez-Chessa, J.; Haidar, Z. S.; Olate, S. \& Iwaki-Filho, L. COVID-19 and dentistry: a review of recommendations and perspectives for Latin America. Int. J. Odontostomat., 14(3):299-309, 2020

Xu, H.; Zhong, L.; Deng, J.; Peng, J.; Dan, H.; Zeng, X.; Li, T. \& Chen, Q. High expression of ACE2 receptor of 2019-nCoV on the epithelial cells of oral mucosa. Int. J. Oral Sci., 12:8, 2020.
Corresponding author:

Sebastián Pérez, DDS, MSc,

Universidad de Sevilla, Sevilla

Faculty of Dentistry

Department of Stomatology

PC: 41001 Seville St., Avicena

ESPAÑA

Email: sebpererr@alum.us.es 